DOI: https://doi.org/10.24127/ajpm.v10i2.3662

\title{
KEMAMPUAN AWAL : BAGAIMANA PEMAHAMAN KONSEP SISWA PADA MATERI TEOREMA PYTHAGORAS?
}

\author{
Nurul Azizah $^{1^{*}}$, Budiyono $^{2}$, Siswanto $^{3^{*}}$ \\ ${ }^{1 *}$ Postgraduate Program of Mathematics Education, Universitas Sebelas Maret, Indonesia \\ ${ }^{2}$ Faculty of Teacher Training and Education, Universitas Sebelas Maret, Indonesia \\ ${ }^{3}$ Faculty of Mathematics and Natural Sciences, Universitas Sebelas Maret, Indonesia \\ ${ }^{*}$ Corresponding author.
E-mail: $\quad$ nurulazizah23@student.uns.ac.id ${ }^{\left.1^{*}\right)}$
budiyono@staff.uns.ac.id ${ }^{2)}$
sis.mipauns@yahoo.co.id $^{3)}$

Received 04 April 2021; Received in revised form 14 June 2021; Accepted 29 June 2021

\begin{abstract}
Abstrak
Salah satu kemampuan dasar yang harus dimiliki siswa dalam belajar matematika adalah kemampuan pemahaman konsep. Kemampuan ini dipengaruhi dari perbedaan kemampuan awal matematika masing masing siswa. Tujuan dari penelitian ini adalah menganalisis pemahaman konsep siswa dalam menyelesaikan soal teorema pythagoras ditinjau dari kemampuan awal siswa. Penelitian ini menggunakan metode deskriptif kualitatif. Teknik analisis data yang digunakan yaitu reduksi data (data reduction), penyajian data (data display), dan penarikan kesimpulan (conclusion drawing or verification). Subjek penelitian adalah 6 siswa kelas VIII SMP Negeri 3 Surakarta. Instrumen penelitian ini menggunakan tes kemampuan pemahaman konsep dan wawancara. Kesimpulan dari penelitian ini yaitu 1) Siswa dengan kemampuan awal tinggi (KAT) memiliki pemahaman konsep yang baik dalam menerapkan konsep dalam perhitungan matematis, menentukan konsepkonsep yang tepat, dan menerjemahkan gambar dalam soal menjadi bentuk lain, 2) Siswa dengan kemampuan awal sedang memiliki pemahaman konsep yang cukup baik dalam menerjemahkan gambar dalam soal menjadi bentuk lain dan menerapkan konsep dalam pertihungan matematis, walaupun masih lemah dalam siswa mampu menentukan konsep-konsep yang tepat untuk digunakan dalam menyelesaikan soal, 3) Siswa dengan kemampuan awal rendah memiliki pemahaman konsep yang cukup baik dalam menerjemahkan gambar dalam soal menjadi bentuk lain walaupun masih lemah pada aspek menerapkan konsep dalam pertihungan matematis dan menentukan konsep-konsep yang tepat untuk digunakan dalam menyelesaikan soal.
\end{abstract}

Kata kunci: Kemampuan awal; pemahaman konsep; dan teorema pythagoras.

\begin{abstract}
One of the basic skills that students must have in learning mathematics is the ability to understand concepts. This ability is influenced by the difference in the initial math ability of each student. The purpose of this study is to analyze the understanding of student concepts in solving pythagoras theorem problems reviewed from the students' initial abilities. This study uses qualitative descriptive methods. Data analysis techniques used are data reduction (data reduction), presentation of data (display data), and conclusion drawing orverification. The subject of the study was 6 grade VIII students of SMP Negeri 3 Surakarta. This research instrument uses concept comprehension and interview skills tests. The conclusion of this study is 1) Students with high initial ability (KAT) have a good understanding of concepts in mathematical calculations, determine the right concepts, and translate images in the question into other forms, 2) Students with early abilities are having a good understanding of concepts in translating images in the question into other forms and applying concepts in mathematical declarations, although still weak in students are able to determine the right concepts to use in solving problems, 3) Students with low initial ability have a good understanding of concepts in translating images in the question into other forms although still weak on the aspect of applying concepts in mathematical declarations and determining the right concepts to use in solving problems.
\end{abstract}

Keywords: Conceptual understanding; initial ability; and pythagoras theorem.

This is an open access article under the Creative Commons Attribution 4.0 International License 
DOI: https://doi.org/10.24127/ajpm.v10i2.3662

\section{PENDAHULUAN}

Pemahaman konsep menjadi salah satu faktor penting yang harus dimiliki oleh siswa sebagai hasil dari proses pembelajaran, kemampuan ini dapat dikembangkan dalam pembelajaran matematika (Fahrudin, 2018; Fatri et al., 2019; Kartika, 2018; Netriwati, 2018). Seorang siswa yang telah menguasai pemahaman konsep berarti telah melewati proses memorizing dan telah berhasil memaknai arti dari suatu konsep yang ditandai dengan kemampuan mengonstruksi pesan melalui lisan, tulisan maupun grafik (Nasution \& Hafizah, 2020) mampu menjelaskan kembali konsep yang didapatkannya dan mampu memberikan contoh-contoh terkait konsep tersebut (Panaoura et al., 2017) memberikan pengertian bahwa materi-materi yang diajarkan kepada siswa bukan hanya sebagai hafalan.

Beberapa penelitian yang membahas mengenai kemampuan pemahaman konsep siswa dipengaruhi berdasarkan perbedaan kemampuan awal siswa, hal tersebut didasari karena kemampuan awal seseorang merupakan pondasi utama yang akan memberikan petunjuk dan menyelaraskan pengetahuan yang baru dipelajari dengan pengetahuan sebelumnya ( $\mathrm{F}$. Lestari et al. 2019; Nasution and Hafizah 2020; Latif, 2017; Rambe et al., 2020). Apabila kemampuan awal yang dimiliki siswa baik, maka akan mendukung peningkatan kemampuan pemahaman konsep yang baik. Menurut Rennita (2018) tidak hanya penggunaan model pembelajaran yang dapat mempengaruhi hasil dan prestasi belajar siswa, namun, kemampuan awal matematika merupakan pondasi utama yang harus dimiliki. Siswa yang mempunyai kemampuan awal yang baik akan lebih cepat memahami materi dibandingkan dengan siswa yang tidak mempunyai kemampuan awal dalam proses pembelajaran (Yusri \& Sari, 2017).

Rendahnya pemahaman konsep siswa dalam pembelajaran matematika merupakan masalah yang sering dijumpai, seperti yang ditemukan di Surakarta (Setiorini et al., 2017), Lampung (Sari et al., 2017), Sukoraja, Jawa Tengah (Sayekti et al., 2019), dan masih banyak lagi sekolah lainnya yang juga menemukan masalah yang sama. Permasalahan yang sering terjadi saat ini yaitu siswa kesulitan dalam memahami suatu konsep, terlebih dalam memahami konsep kerap kali bersifat abstrak (Fuadiah, 2020).

Berdasarkan hasil wawancara dengan guru, rendahnya pemahaman konsep siswa dipengaruhi oleh kurangnya kemampuan siswa membentuk suatu konsep dalam diri dan kesiapan dalam menerima pelajaran yang belum maksimal. Selain itu, terdapat beberapa faktor internal lainnya, yaitu self efficacy siswa yang rendah membuat lebih mudah menyerah saat menemukan kesulitan dalam memahami materi bahkan sulit dalam memecahkan masalah. Selain itu, kemampuan awal siswa yang rendah menjadi faktor keberhasilan dalam proses pembelajaran. Kemampuan awal dinilai sebagai kesenjangan yang ada di lapangan karena kemampuan awal merupakan titik awal dalam proses pembelajaran. Hal tersebut sesuai dengan hasil penelitian Purwaningrum \& Sumardi (2016) bahwa kemampuan awal matematika yang dimiliki oleh siswa merupakan faktor yang paling berpengaruh terhadap hasil belajar.

Kemampuan awal merupakan kumpulan dari beberapa pengetahuan dasar yang dipergunakan sebagai syarat dalam mengikuti pembelajaran 
DOI: https://doi.org/10.24127/ajpm.v10i2.3662

(Suparni, 2019: 115). Sehingga, kemampuan awal siswa sangat mempengaruhi dan berkontribusi terhadap tolak ukur keberhasilan proses pembelajaran dan efisiensi belajar (Rambe et al., 2020). Belum ditemukan penelitian yang menganalisis pemahaman konsep matematis siswa SMP Negeri 3 Surakarta ditinjau dari kemampuan awal khususnya pada materi teorema pythagoras. Oleh karena itu, tujuan dari penelitian ini adalah menganalisis pemahaman konsep siswa ditinjau berdasarkan perbedaan kemampuan awal.

\section{METODE PENELITIAN}

Penelitian ini menggunakan metode deskriptif dengan pendekatan kualitatif yang merupakan metode yang berusaha menggambarkan dan menginterpretasikan objek sesuai dengan apa adanya. Penelitian ini dilakukan dengan materi teorema pythagoras dan subjek yang diambil adalah 6 siswa kelas VIII SMP Negeri 3 Surakarta semester ganjil tahun ajaran 2021/2022. Teknik pengambilan subjek menggunakan purposive sampling sehingga subjek yang diambil yaitu terdiri dari 3 kelompok, yaitu 2 siswa dengan kemampuan awal rendah, 2 siswa dengan kemampuan awal sedang, dan 2 siswa dengan kemampuan tinggi.

Variabel yang diukur merupakan pemahaman konsep siswa kelas VIII SMP Negeri 3 Surakarta. Instrumen dalam penelitian ini adalah tes kemampuan pemahaman konsep yang merupakan bentuk tes uraian agar dapat melihat pemahaman konsep siswa. Validitas data dalam penelitian ini menggunakan metode triangulasi. Teknik analisis data yang digunakan yaitu reduksi data (data reduction), penyajian data (data display), dan penarikan kesimpulan (conclusion drawing or verification). Adapun tahapan dalam penelitian ini, sebagai berikut:

1. Melakukan observasi ke sekolah, menentukan kelas penelitian, menetapkan pokok bahasan yang digunakan, dan menyusun instrumen penelitian berupa tes.

2. Memberikan tes kemampuan awal pada materi teorema pythagoras kepada siswa kelas VIII untuk mengukur dan mengelompokkan tingkatan kemampuan awal yang dimiliki siswa.

3. Menetapkan kategori kemampuan awal siswa dalam ketiga kelompok yang dipilih berdasarkan kriteria penilaian acuan patokan (PAP), yang dimodifikasikan oleh Budiyono (2016) yang terangkum pada Tabel 1.

Tabel 1 PAP kemampuan awal

\begin{tabular}{cc}
\hline Skor & Kategori \\
\hline $70<$ skor $\leq 100$ & Tinggi \\
$30<$ skor $\leq 70$ & Sedang \\
$0<$ skor $\leq 30$ & Rendah \\
\hline
\end{tabular}

4. Memilih dua subjek dari setiap kategori kemampuan awal tinggi, sedang, dan rendah. Subjek yang dipilih adalah subjek yang sudah didiskusikan bersama guru dengan pertimbangan bahwa siswa tersebut sudah menerima materi teorema pythagoras, siswa mampu mengkomunikasikan pikirannya baik lisan maupun tulisan dengan baik, dan subjek bersedia berpartisipasi dalam pengambilan data selama penelitian.

5. Memberikan soal tes pemahaman konsep materi teorema pythagoras pada siswa kelas VIII untuk mendiagnosis gambaran pemahaman konsep siswa. 
6. Melaksanakan wawancara dengan siswa setelah tes dilaksanakan. Wawancara ini bersifat semiterstruktur, dimana dipersiapkan terlebih dahulu daftar pertanyaan yang berisi pokok-pokok pertanyaan sebagai penuntun selama proses wawancara.

\section{HASIL DAN PEMBAHASAN}

Berikut akan dipaparkan hasil penelitian sekaligus analisis data yang didapatkan. Hasil penelitian yang diperoleh adalah berupa tes kemampuan pemahaman konsep dan wawancara. Tes yang diberikan kepada siswa sebanyak 3 soal dan 1 soal memiliki 1 indikator, dimana indikator tersebut yaitu, 1) siswa mampu menerapkan konsep dalam pertihungan matematis untuk menyelesaikan soal atau menyimpulkan dari sesuatu yang telah diketahui (extrapolation), 2) siswa mampu menentukan konsep-konsep yang tepat untuk digunakan dalam menyelesaikan soal (interpretation), 3) siswa mampu menerjemahkan kalimat dalam soal menjadi bentuk kalimat lain (translation). Berikut dipaparkan hasil rangkuman analisis kemampuan pemahaman konsep siswa berdasarkan masing-masing indikator seperti pada Tabel 2 sampai Tabel 4.

Tabel 2 Analisis pemahaman konsep siswa berkemampuan awal tinggi

\begin{tabular}{|c|c|c|c|}
\hline \multirow{2}{*}{ Subjek } & \multicolumn{3}{|c|}{ Indikator } \\
\hline & extrapolation & interpretation & translation \\
\hline ST-01 & $\begin{array}{l}\text { Pada soal pertama } \\
\text { dengan indikator } \\
\text { extrapolation, ST-01 } \\
\text { mampu } \\
\text { menyimpulkan dengan } \\
\text { baik informasi yang di } \\
\text { paparkan, mampu } \\
\text { mengilustrasikan } \\
\text { sketsa gambar yang } \\
\text { tepat ke dalam bentuk } \\
\text { penyelesaian dengan } \\
\text { benar menggunakan } \\
\text { teorema pythagoras. }\end{array}$ & $\begin{array}{l}\text { Pada soal kedua dengan } \\
\text { indikator interpretation, } \\
\text { secara garis besar ST- } \\
01 \text { mampu memahami } \\
\text { ide utama dari soal } \\
\text { secara tepat dan } \\
\text { menjawab soal dengan } \\
\text { baik namun ST-01 tidak } \\
\text { menjabarkan secara } \\
\text { detail bagaimana ST-01 } \\
\text { bisa mendapatkan } \\
\text { selisih tinggi kedua } \\
\text { buah tiang. }\end{array}$ & $\begin{array}{l}\text { Pada soal ketiga dengan } \\
\text { indikator translation, } \\
\text { ST-01 mampu } \\
\text { menerjemahkan gambar } \\
\text { sebuah balok yang } \\
\text { diberikan pada soal } \\
\text { menjadi bentuk } \\
\text { jawaban penyelesaian } \\
\text { yang terstruktur } \\
\text { menggunakan teorema } \\
\text { pythagoras dengan } \\
\text { tepat. }\end{array}$ \\
\hline S & $\begin{array}{l}\text { Pada soal pertama } \\
\text { dengan indikator } \\
\text { extrapolation, ST-02 } \\
\text { mampu } \\
\text { menyimpulkan } \\
\text { informasi } \\
\text { paparkan, ST-02 juga } \\
\text { menerapkan konsep } \\
\text { menggunakan teorema } \\
\text { pythagoras dengan } \\
\text { tepat rantuk } \\
\text { menyelesaikan soal. }\end{array}$ & $\begin{array}{l}\text { Pada soal kedua dengan } \\
\text { indikator interpretation, } \\
\text { ST-02 mampu } \\
\text { memahami soal secara } \\
\text { baik yang peneliti } \\
\text { paparkan dan ST-02 } \\
\text { juga dapat menentukan } \\
\text { konsep-konsep yang } \\
\text { tepat untuk digunakan } \\
\text { dalam menyelesaikan } \\
\text { soal. }\end{array}$ & $\begin{array}{l}\text { Pada soal ketiga dengan } \\
\text { indikator translation, } \\
\text { ST-02 mampu } \\
\text { menerjemahkan gambar } \\
\text { menggunakan teorema } \\
\text { pythagoras menjadi } \\
\text { bentuk penyelesaian, } \\
\text { ST-02 memahami dan } \\
\text { menjawab soal dengan } \\
\text { baik. }\end{array}$ \\
\hline
\end{tabular}


Berdasarkan data pada Tabel 2, diketahui bahwa 8 siswa berkemampuan awal tinggi, sehingga untuk memperoleh data yang lebih mendalam maka memilih 2 subjek yang memenuhi kriteria untuk diwawancara. Berdasarkan hasil analisis jawaban siswa dari kelompok kemampuan awal matematis tinggi pada tabel 1,2, dan 3 di atas, terlihat bawah kedua siswa mampu mengerjakan soal pada indikator extrapolation, interpretation, translation. Kedua siswa pada kemampuan awal tinggi (KAT) mampu menerapkan konsep dalam perhitungan matematis untuk menyelesaikan soal dan menyimpulkan yang diketahui menggunakan teorema pythagoras dengan tepat, siswa juga mampu menentukan konsep-konsep yang tepat untuk digunakan dalam menyelesaikan soal pythagoras, dan kedua siswa mampu menerjemahkan gambar sebuah balok yang diberikan dalam bentuk kalimat dan jawaban penyelesaian dengan tepat.

Tabel 3 Analisis pemahaman konsep siswa berkemampuan awal sedang

\begin{tabular}{|c|c|c|c|}
\hline \multirow{2}{*}{ Subjek } & \multicolumn{3}{|c|}{ Indikator } \\
\hline & extrapolation & interpretation & translation \\
\hline SS-01 & $\begin{array}{lr}\text { Pada soal } & \text { pertama } \\
\text { dengan } & \text { indikator } \\
\text { extrapolation, } & \text { SS-01 } \\
\text { mampu } & \text { menangkap } \\
\text { perintah } & \text { dan } \\
\text { menentukan } & \text { sketsa } \\
\text { gambar dari } & \text { soal yang } \\
\text { diberikan } & \text { sehingga } \\
\text { SS-01 } & \text { dapat } \\
\text { menjawab pertanyaan } \\
\text { dengan baik. }\end{array}$ & $\begin{array}{l}\text { Pada soal kedua dengan } \\
\text { indikator interpretation, } \\
\text { SS-01 tidak mampu } \\
\text { menyimpulkan yang } \\
\text { diketahui dari soal, } \\
\text { memahami soal dengan } \\
\text { baik sehingga SS-01 } \\
\text { tidak dapat menjawab } \\
\text { dan menyelesaiakan } \\
\text { soal dengan tepat. }\end{array}$ & $\begin{array}{l}\text { Pada soal ketiga dengan } \\
\text { indikator translation, } \\
\text { SS-01 mampu } \\
\text { menerjemahkan konsep } \\
\text { dari gambar balok, SS- } \\
01 \text { menjawab soal } \\
\text { menggunakan teorema } \\
\text { pythagoras dengan } \\
\text { baik. }\end{array}$ \\
\hline SS-02 & $\begin{array}{lr}\text { Pada soal pertama } \\
\text { dengan indikator } \\
\text { extrapolation, SS-02 } \\
\text { mampu } \\
\text { menyimpulkan dengan } \\
\text { baik informasi yang } \\
\text { diberikan } & \text { dan } \\
\text { menuliskan secara } \\
\text { detail apa yang } \\
\text { diketahui dari } & \text { soal, } \\
\text { SS-02 } & \text { mampu } \\
\text { menjawab soal dengan } \\
\text { baik dan lengkap. }\end{array}$ & $\begin{array}{l}\text { Pada soal kedua dengan } \\
\text { indikator interpretation, } \\
\text { SS-02 belum } \\
\text { memahami ide utama } \\
\text { dari soal yang diberikan } \\
\text { dan bingung dalam } \\
\text { menyimpulkan hasil } \\
\text { yang ia dapat sehingga } \\
\text { jawaban yang diberikan } \\
\text { belum maksimal. }\end{array}$ & $\begin{array}{l}\text { Pada soal ketiga dengan } \\
\text { indikator translation, } \\
\text { SS-02 mampu } \\
\text { menerjemahkan gambar } \\
\text { balok yang diberikan } \\
\text { dalam bentuk jawaban } \\
\text { penyelesaian dan } \\
\text { menjawab soal dengan } \\
\text { baik.. }\end{array}$ \\
\hline
\end{tabular}

Selain itu juga didapati 10 siswa dengan kemampuan awal sedang, dari 10 siswa tersebut peneliti memilih 2 subjek yang memenuhi kriteria untuk diwawancarai. Berdasarkan hasil analisis jawaban dari kelompok kemampuan awal matematis sedang pada Tabel 3 di atas, terlihat bawah kedua siswa memenuhi indikator translation dan extrapolation, namun 
belum mampu memenuhi indikator interpretation. Kedua siswa tersebut mampu menerjemahkan gambar yang ada di dalam soal menjadi bentuk penyelesaian yang baik menggunakan teorema pythagoras walaupun siswa sedikit tidak teliti dan pada indikator extrapolation kedua siswa dapat menentukan sketsa gambar dari penjelasan soal yang diberikan. Pada indikator interpretation, kedua siswa tidak mampu menyimpulkan yang diketahui dari soal, tidak memahami soal dengan baik sehingga tidak dapat menyelesaiakan soal dengan baik.

Tabel 4 Analisis pemahaman konsep siswa berkemampuan awal rendah

\begin{tabular}{|c|c|c|c|}
\hline Subjek & extrapolation & $\begin{array}{c}\text { Indikator } \\
\text { interpretation }\end{array}$ & translation \\
\hline SR-01 & $\begin{array}{l}\text { Pada soal pertama } \\
\text { dengan indikator } \\
\text { extrapolation, SR-01 } \\
\text { tidak dapat menjawab } \\
\text { dan menyimpulkan } \\
\text { hasil yang ia diperoleh } \\
\text { karena SR-01 merasa } \\
\text { bingung dalam } \\
\text { menerapkan konsep } \\
\text { soal dalam bentuk } \\
\begin{array}{l}\text { penyelesaian teorema } \\
\text { pythagoras. }\end{array}\end{array}$ & $\begin{array}{l}\text { Pada soal kedua dengan } \\
\text { indikator interpretation, } \\
\text { SR-01 belum mengerti } \\
\text { apa yang diminta soal. } \\
\text { SR-01 kebingungan } \\
\text { untuk menentukan apa } \\
\text { yang diketahui dan } \\
\text { menerapkan teorema } \\
\text { pythagoras ke dalam } \\
\text { soal. }\end{array}$ & $\begin{array}{l}\text { Pada soal ketiga dengan } \\
\text { indikator translation, } \\
\text { SR-01 mampu } \\
\text { menerjemahkan gambar } \\
\text { balok menjadi bentuk } \\
\text { penyelesaian yang baik } \\
\text { menggunakan teorema } \\
\text { pythagoras, jawaban } \\
\text { yang diberikan SR-01 } \\
\text { lengkap dan tepat. }\end{array}$ \\
\hline SI & $\begin{array}{l}\text { Pada soal pertama } \\
\text { dengan indikator } \\
\text { extrapolation, SR-02 } \\
\text { tidak memahami dan } \\
\text { menangkap informasi } \\
\text { yang diberikan pada } \\
\text { soal sehingga SR-02 } \\
\text { tidak dapat } \\
\text { menentukan jarak } \\
\text { dengan menggunakan } \\
\text { teorema pythagoras. }\end{array}$ & $\begin{array}{l}\text { Pada soal kedua dengan } \\
\text { indikator interpretation, } \\
\text { SR-02 tidak dapat } \\
\text { menyimpulkan yang } \\
\text { diketahui dari soal, } \\
\text { memahami soal dengan } \\
\text { baik dan menjawab soal } \\
\text { secara tepat } \\
\text { menggunakan teorema } \\
\text { pythagoras. }\end{array}$ & $\begin{array}{l}\text { Pada soal ketiga dengan } \\
\text { indikator translation, } \\
\text { SR-02 mampu } \\
\text { menerjemahkan konsep } \\
\text { dari gambar balok, SR- } \\
02 \text { menangkap } \\
\text { informasi dengan baik } \\
\text { sehingga SR-02 dapat } \\
\text { menerapkan teorema } \\
\text { pythagoras ke dalam } \\
\text { soal. }\end{array}$ \\
\hline
\end{tabular}

Selain itu, terdapat 6 siswa yang berkemampuan awal rendah, sehingga peneliti memilih 2 subjek yang memenuhi kriteria untuk diwawancarai. Berdasarkan hasil analisis jawaban dari kelompok kemampuan awal matematis sedang pada tabel 3 di atas, terlihat bawah kedua siswa tidak memenuhi indikator interpretation dan extrapolation, namun pada translation kedua siswa sama-sama memenuhi indikator. Baik SR-01 maupun SR-02 pada indikator extrapolation tidak mampu menerapkan konsep dalam pertihungan matematis menggunakan teorema pythagoras untuk menyelesaikan soal dan menyimpulkan yang diketahui. Kedua siswa juga tidak mampu menentukan konsep yang ditentukan untuk menyelesaikan soal. Namun, kedua siswa baik SR-01 maupun SR-02 mampu menerjemahkan 
gambar sebuah balok yang diberikan dalam bentuk kalimat dan jawaban penyelesaian dengan tepat.

Berdasarkan temuan penelitian yang telah dijabarkan maka diketahui bahwa siswa dengan kelompok kemampuan awal tinggi memiliki kemampuan pemahaman konsep yang baik. Siswa yang memiliki kemampuan awal tinggi, secara baik dapat menerapkan konsep dalam perhitungan matematis, menentukan konsep-konsep yang tepat, dan menerjemahkan kalimat atau gambar dalam bentuk lain. Siswa dengan kemampuan awal sedang memiliki pemahaman konsep yang baik dalam menerjemahkan kalimat atau gambar dalam bentuk lain, siswa juga mampu menerapkan konsep dalam pertihungan matematis untuk menyelesaikan soal. Namun, kedua siswa tidak menguasai indikator interpretation sehingga tidak dapat menentukan konsep-konsep yang tepat untuk digunakan dalam menyelesaikan soal. Pada kelompok siswa berkemampuan awal rendah, siswa mampu memenuhi menerjemahkan kalimat atau gambar dalam bentuk lain namun siswa masih sulit dalam menentukan konsep-konsep yang tepat untuk digunakan dalam menyelesaikan soal dan menerapkan konsep dalam pertihungan matematis untuk menyimpulkan apa yang telah diketahui.

Berdasarkan paparan yang dijelaskan di atas dapat disimpulkan bahwa siswa dengan kemampuan awal yang tinggi memiliki kemampuan pemahaman konsep yang baik. Hal tersebut mengindikasikan apabila seorang siswa yang mempunyai kemampuan awal yang baik akan lebih cepat memahami materi dibandingkan dengan siswa yang mempunyai kemampuan awal rendah pada saat proses pembelajaran berlangsung.
Siswa dengan kemampuan awal yang lebih tinggi akan lebih mudah untuk memahami suatu konsep. Konstruksi konsep yang akan dipelajari oleh suatu individu sangat dipengaruhi oleh kemampuan awalnya, sehingga pembelajaran yang berorientasi pada pengetahuan awal diyakini akan memberikan dampak pada proses dan perolehan belajar yang memadai. Hal tersebut senada dengan penelitian yang dilakukan oleh Payung (2018) yaitu apabila kemampuan awal siswa tinggi, dalam proses belajar berikutnya siswa tersebut akan lebih mudah memahami konsep materi dan tidak akan mengalami kesulitan. Namun apabila kemampuan awal siswa rendah, maka siswa akan mengalami kesulitan untuk mencapai tujuan yang diinginkan, sehingga perlu waktu lama untuk memperoleh tujuan yang ingin dicapai.

Hal tersebut sejalan dengan penelitian (Utami \& Anitra, 2019), (Purwati, 2017), (Yusri \& Sari, 2017), dan (Yufentya et al., 2019) bahwa siswa dengan kemampuan awal tinggi memiliki kemampuan pemahaman konsep yang lebih baik dalam indikator extrapolation, interpretation, translation daripada siswa berkemampuan sedang dan rendah. Kemampuan awal siswa merupakan salah satu faktor dari pribadi siswa yang juga merupakan hal penting dalam membantu proses pembelajaran. Kemampuan awal adalah prasyarat yang diperlukan siswa dalam mengikuti pembelajaran agar kedepannya siswa mendapatkan hasil yang baik. Selain itu, kemampuan awal juga mendukung dan mendasari pemahaman siswa terhadap suatu materi sehingga diyakini dapat meningkatkan hasil belajar siswa. Berdasarkan hasil pembahasan di atas, penelitian ini dapat ditarik kesimpulan bahwa kemampuan awal siswa mempengaruhi pemahaman 
konsep dan pemahaman konsep matematika siswa dapat ditingkatkan melalui berbagai cara, salah satunya dengan menerapkan model pembelajaran yang dinilai efektif dalam menunjang proses pembelajaran dan keberhasilan belajar.

\section{KESIMPULAN DAN SARAN}

Berdasarkan hasil dan analisis penelitian yang telah dilakukan maka diperoleh kesimpulan bahwa: 1) Siswa dengan kemampuan awal tinggi (KAT) memiliki pemahaman konsep yang baik dalam menerapkan konsep dalam pertihungan matematis, menentukan konsep-konsep yang tepat , dan menerjemahkan gambar dalam soal menjadi bentuk lain, 2) Siswa dengan kemampuan awal sedang memiliki pemahaman konsep yang cukup baik dalam menerjemahkan gambar dalam soal menjadi bentuk lain dan menerapkan konsep dalam pertihungan matematis, walaupun masih lemah dalam siswa mampu menentukan konsep-konsep yang tepat untuk digunakan dalam menyelesaikan soal, 3) Siswa dengan kemampuan awal rendah memiliki pemahaman konsep yang cukup baik dalam menerjemahkan gambar dalam soal menjadi bentuk lain walaupun masih lemah pada aspek menerapkan konsep dalam pertihungan matematis dan menentukan konsepkonsep yang tepat untuk digunakan dalam menyelesaikan soal.

Berdasarkan penelitian yang telah dilakukan, berharap agar siswa dapat memperbanyak latihan operasi hitung baik dengan soal rutin maupun non rutin dan membiasakan diri untuk mengecek kembali jawaban sebelum dikumpulkan. Pembelajaran matematika yang dikembangkan hendaknya tidak ditekankan untuk menghapalkan rumus akan tetapi bertujuan untuk meningkat- kan penguasaan siswa terhadap konsep materi. Adapun saran bagi peneliti yang akan datang yaitu agar dapat menjadi rujukan, sumber informasi, dan bahan referensi penelitian selanjutnya agar bisa lebih dikembangkan dalam materimateri yang lainnya untuk meningkatkan kualitas pembelajaran.

\section{DAFTAR PUSTAKA}

Budiyono. (2016). Pengantar Penilaian hasil Belajar. UNS Press.

C, G., S, C., L, C., C, M., V, S., \& S, J. (2018). Understanding arithmetic concepts: The Role of DomainSpecific and Domain-General Skills. PLoS ONE Journal, 13(9).

Fachrurrozy, M., \& Saehana, S. (2017). Error analysis of mathematical concepts in students of Physical education courses. E-Jurnal Mitra Sains, 5(2), 1-10.

Fahrudin. (2018). Pembelajaran Problem Solving Modifikasi untuk Meningkatkan Kemampuan Pemahaman Konsep Matematis Siswa SMP 1. Desimal: Jurnal Matematika, 1(2), 181-189.

Fatri, F. F., Maison, M., \& Syaiful, S. (2019). Kemampuan Representasi Matematis Siswa Kelas VIII SMP Ditinjau dari Gaya Kognitif Visualizer dan Verbalizer. Jurnal Didaktik Matematika, 6(2), 98111.

Fuadiah, N. F. (2020). Miskonsepsi Sebagai Hambatan Belajar Siswa Dalam Memahami Matematika. Jurnal Ilmu Pendidikan (JIP) STKIP, 7(2), 1689-1699.

Huda, S., Firmansyah, M., Rinaldi, A., Suherman, S., Sugiharta, I., Astuti, D. W., Fatimah, O., \& Prasetyo, andika E. (2019). Understanding of Mathematical Concepts in the Linear Equation with Two Variables: Impact of E- 
DOI: https://doi.org/10.24127/ajpm.v10i2.3662

Learning and Blended Learning Using Google Classroom. AlJabar: Jurnal Pendidikan Matematika, 10(2), 261-270.

Kartika, Y. (2018). Analisis kemampuan pemahaman konsep matematis peserta didik kelas vii smp pada materi bentuk aljabar. Jurnal Pendidikan Tambusai, 2(58), 777-785.

Latif, S. (2017). Mathematical Connection Ability in Solving Mathematics Problem Based on Initial Abilities of Students At Smpn 10 Bulukumba. Jurnal Daya Matematis, 4(2), 207.

Lestari, F., Saryantono, B., Syazali, M., Saregar, A., Jauhariyah, D., \& Umam, R. (2019). Cooperative Learning Application with the Method of Network Tree Concept Map: Based on Japanese Learning System Approach. Journal for the Education of Gifted Young Scientists, 7(1), 1532.

Lestari, L., \& Surya, E. (2017). The Effectiveness of Realistic Mathematics Education Approach on Ability of Students , Mathematical Concept Understanding. International Journal of Sciences: Basic and Applied Research (IJSBAR), 34(1), 91-100.

Nasution, M. L., \& Hafizah, N. (2020). Development of students' understanding of mathematical concept with STAD type cooperative learning through student worksheets. Journal of Physics: Conference Series, 1554, 012035.

Netriwati. (2018). Penerapan Taksonomi Bloom Revisi untuk Meningkatkan Kemampuan Pemahaman Konsep Matematis.
Desimal: Jurnal Matematika, 1(3), 347-352.

Panaoura, A., Michael-Chrysanthou, P., Gagatsis, A., Elia, I., \& Philippou, A. (2017). A Structural Model Related to the Understanding of the Concept of Function: Definition and Problem Solving. International Journal of Science and Mathematics Education, 15(4), 723-740.

Payung, L. M., Ramadhan, A., \& Made, I. (2018). Pengaruh Pengetahuan Awal, Kecerdasan Emosional, dan Motivasi Belajar terhadap Hasil Belajar IPA Siswa Kelas VIII SMP Negeri 3 Parigi. E-Jurnal Mitra Sains.

Purwaningrum, D., \& Sumardi, S. (2016). Efek Strategi Pembelajaran Ditinjau dari Kemampuan Awal Matematika terhadap Hasil Belajar Matematika Kelas XI IPS. Manajemen Pendidikan.

Purwati, S. (2017). Pengaruh Kemampuan Awal terhadap Pemahaman Konsep Usaha dan Energi. In Prosiding SNFA (Seminar Nasional Fisika dan Aplikasinya) (Vol. 1, p. 100).

Rambe, N., Syahputra, E., \& Elvis, E. (2020). The Effect of the Jigsaw Cooperative Learning Model and the Student's Initial Mathematical Abilities and Its Effect on the Mathematical Representation Ability and Learning Motivation of Students in the PAB 10 Sampali Private Elementary School. Budapest International Research and Critics in Linguistics and Education (BirLE) Journal, 3(3), 1591-1599.

Rennita, O. D. (2018). The Differences of Improving Communication Ability and Mathematical 
Concepts Understanding between Students that Given Problem Based Learning and Discovery Learning at SMP Swasta AlHikmah Medan. Advances in Social Sciences Research Journal, 5(10), 597-608.

Rusmini, \& Surya, E. (2017). The Effect of Numbered Heads Together Model Against Students ' Mathemacal Concept Mastery in SMP Negeri 8 Medan. IJARIIE, 3(2), 3433-3440.

Sagala, R., Umam, R., Thahir, A., Saregar, A., \& Wardani, I. (2019). The Effectiveness of STEMBased on Gender Differences: The Impact of Physics Concept Understanding. European Journal of Educational Research, 8(3), 753-761.

Sari, W. P., Suyanto, E., \& Suana, W. (2017). Analisis Pemahaman Konsep Vektor pada Siswa Sekolah Menengah Atas. Jurnal Ilmiah Pendidikan Fisika AlBiruni, 06(2).

Sayekti, Y., Studi, P., Matematika, P., \& Purwokerto, U. M. (2019). Pengaruh Problem Based Learning dengan Strategi "MURDER " terhadap Kemampuan Pemahaman Konsep Matematis Siswa. Journal of Mathematics Education, 5(1), 2432.

Setiorini, I. A., Pramudya, I., \& Setiawan, R. (2017). Analisis Pemahaman Konsep Siswa terhadap Materi Pokok Statistika ditinjau dari Kebiasaan Belajar Matematika pada Siswa Kelas XII IPS 1 SMA Negeri 6 Surakarta Tahun Pelajaran 2016/2017. Jurnal Pendidikan Matematika Dan Matematika (JPMM) Solusi, 1(4), 1-14.
Suparni. (2019). Kemampuan Awal Matematika Mahasiswa Baru Prodi Tadris/Pendidikan Matematika IAIN Padangasidimpuan T.A 2017/2018. Jurnal Ilmu-Ilmu Pendidikan Dan Sains, 7(01), 111-122.

Utami, C., \& Anitra, R. (2019). Kemampuan Pemahaman Konsep Matematis Mahasiswa Ditinjau Dari Kemampuan Awal Pada Mata Kuliah Matematika SD. Jurnal Keilmuan Dan Kependidikan Dasar, 11(02), 103-110.

Yufentya, W. E., Roza, Y., \& Maimunah, M. (2019). Analisis Kemampuan Pemahaman Konsep Siswa Kelas VIII SMP pada Materi Lingkaran. Desimal: Jurnal Matematika, 2(3), 197202.

Yusri, A. Y., \& Sari, M. (2017). Profil Pemahaman Konsep Nilai Tempat Ditinjau Dari Kemampuan Awal Matematika Pada Siswa Kelas III SDN 133 Takalala Soppeng. Journal Mosharafa, 6(1), 141152. 